\title{
Identification of valuable varieties of oats for food purposes in the conditions of the South of Western Siberia
}

\author{
E.Yu. Ignatieva, and I.V. Pakhotina* \\ Omsk ARC, Omsk, Russia
}

\begin{abstract}
The article presents the results of a study of samples of glumaceous and hulless oat grown in the conditions of the southern foreststeppe of Western Siberia for cereal properties. The features of assessing the quality of grain of various forms of oat are considered. The research was carried out in the grain quality laboratory of the Omsk ARC in 20182020. It was found that hulless forms of oat had an advantage in terms of protein content in grain, nature and yield of cereals in comparison with glumaceous varieties. The glumaceous samples formed a yield $29.6 \%$ higher than the hulless ones, and were also distinguished by a lower content of fine grain and a higher weight of 1000 grains. High variation coefficients were determined for the protein content in the grain, the nature and weight of 1000 grains. Correlation analysis revealed a close dependence of the yield of cereal on the nature of the grain, its size and the content of glumas for glumeacous forms, and for hulless with the nature of grain. The glumeacous varieties Uran and Mutika 1178 and hulless Tarsky golozerny, Inermis 1194 and 1189 are recommended for the production of high-quality cereals in the conditions of the South of Western Siberia.
\end{abstract}

\section{Introduction}

Agriculture as a production branch should provide the population with grain and food in the necessary quantity and of high quality. To organize a full-fledged diet of the population, various agricultural crops for baking, pasta and cereals are needed, such as wheat, oat, barley, buckwheat and others. Porridges based on cereals from grain crops (wheat, oat, barley, etc.) enrich the human diet with vitamins, trace elements, various fibers that ensure the healthy functioning of the body. In recent decades, oat has become increasingly important as a food grain, due to its valuable chemical composition. Its grain contains a large amount of starch (up to $60 \%$ ), proteins, vitamins B, C, fats, sugars, free amino acids, saponins, flavonoids, phytic acids [1]. The unique composition of the grain of this crop allows it to be used in the food industry. The increased demand for new processed products has led to the creation of new varieties of oat with specific properties by breeders. This is an increased level of $\beta$-glucans, antioxidants and omega-3 fatty acids, as well as starch and protein [2]. Currently, according to the Food and Agriculture Organization of the United

\footnotetext{
* Corresponding author: pakhotina@anc55.ru
} 
Nations (FAO), Russia occupies the first place in the world in the production of oat. The top five includes Canada (second place), as well as Spain, Australia and Poland. In 2018, these countries accounted for $43 \%$ of world oat production [3]. One of the main products of processing of this graminaceous plant is cereals. The domestic industry fully meets the needs of the country's population in the main types of cereals of different commodity grades, numbers and trademarks. The structure of grain production is shown in Figure 1[4].

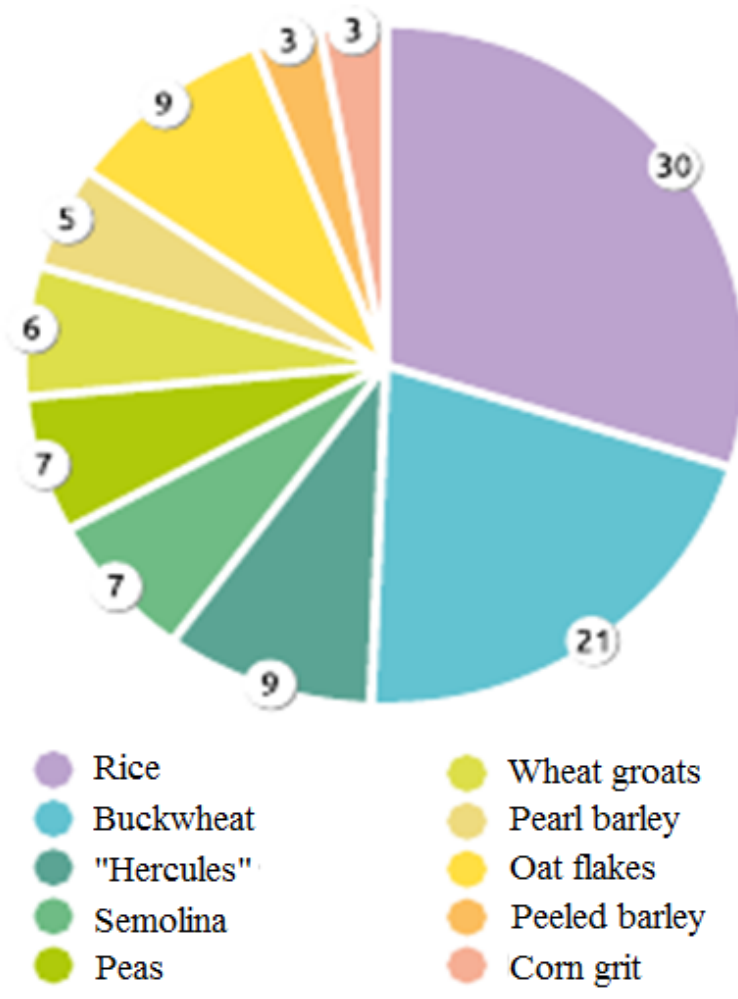

Fig. 1. Structure of cereals production in the Russian Federation, \%.

The figure shows that oat processing products are widely represented in the form of "Hercules" cereals and oat flakes. In addition to cereals, oat, like soy, can be used for the production of milk drinks rich in various trace elements and unsaturated fats. Therefore, oatmeal and soy milk can be used to diversify and enrich human nutrition [5]. For the production of cereals, in addition to glumaceous oat, its hulless forms also have a perspective. Cereals and flakes from hulless oat have better taste qualities compared to those of filmy varieties, due to a higher protein and fat content. The production of food concentrates from hulless oat simplifies the production process, increases the output of finished products by $20 \ldots 25 \%$ and reduces its cost. It has a higher nutritional and energy value when used for feed purposes [6]. The disadvantage of hulless forms is the presence of glumas from 0.2 to $8.8 \%$ and higher, depending on the growing area, pubescence of the grain, small grain and reduced yield in comparison with glumaceous forms. When breeding for food purposes, preference is given to productive lines with large grain [7]. In modern GOST there are no requirements for the quality of hulless varieties, both oat and barley. The studies conducted in the Omsk ARC in the grain quality laboratory showed that, in general, the evaluation system is not differentiated by glumaceous and hulless forms, but 
the regulations for determining individual indicators, especially the yield of cereals, and their level should differ [8]. Oat is an unpretentious crop, able to tolerate short-term spring frosts and can be grown in the sharply continental conditions of Western Siberia as a fodder and food crop. At the same time, according to the AB Center (ab-centre.ru) in the Russian Federation, there has been a decrease in the acreage of oat since 2000 by almost 2 times. In 2020, oat plantings occupied $3.1 \%$ of the structure of the sown areas of the main agricultural crops. The leaders in terms of gross collections and sown areas are the Altai Krai, the Novosibirsk region and the Krasnoyarsk Krai. The Omsk region occupies approximately the 7 th place in the production of grain of this crop. Based on the unique properties of grain and oat groats, further work on the creation of oat varieties of the grain direction of glumaceous and hulless forms is an urgent task.

The purpose of the research is to identify valuable cereal forms of glumaceous and hulless oat grown in the conditions of the southern forest-steppe of Western Siberia.

\section{Materials and methods}

In 2018 - 2020, 30 glumaceous and hulless samples of oat were studied in the grain quality laboratory of the Omsk ARC from the nursery of competitive variety testing of the laboratory of grain forage breeding. 12 promising forms of glumaceous and 4 - hulless oat were selected, the quality of which is presented in this article. The evaluation of grain properties was carried out according to the methodology of the state commission for variety testing of agricultural crops [9], as well as modified methods developed in the grain quality laboratory [8]. The protein content in the grain was determined by the Kjeldahl method in the modification of M.I. Bazavluk. Mathematical data processing was carried out in accordance with the methodology of B.A. Dospekhov [10]. The meteorological conditions of the growing season of 2018-2020 were diverse, which made it possible to more objectively assess the quality of the grain of the material provided. The conditions of 2018 were characterized by cool temperatures and a large amount of precipitation. In August, the air temperature was $0.4^{\circ} \mathrm{C}$ below normal, and precipitation fell $6 \mathrm{~mm}$ above normal. The growing season of 2019 was characterized by the predominance of cool rainy weather in June, and in August the air temperature was $1.47^{\circ} \mathrm{C}$ higher than normal $(108.9 \%)$. Precipitation fell by $14.9 \mathrm{~mm}$ less than normal (72.9\%). Weather conditions in 2020 were characterized by high temperatures and drought from June to July (23\% of precipitation fell from the average long-term norm). In August, there was a sharp increase in the amount of precipitation, which was $124 \%$ compared to the long-term average annual period. The August temperature was $2.9^{\circ} \mathrm{C}$ higher than the long-term average. The features of the weather conditions of the growing season according to the years of research are shown in Figure 2. 


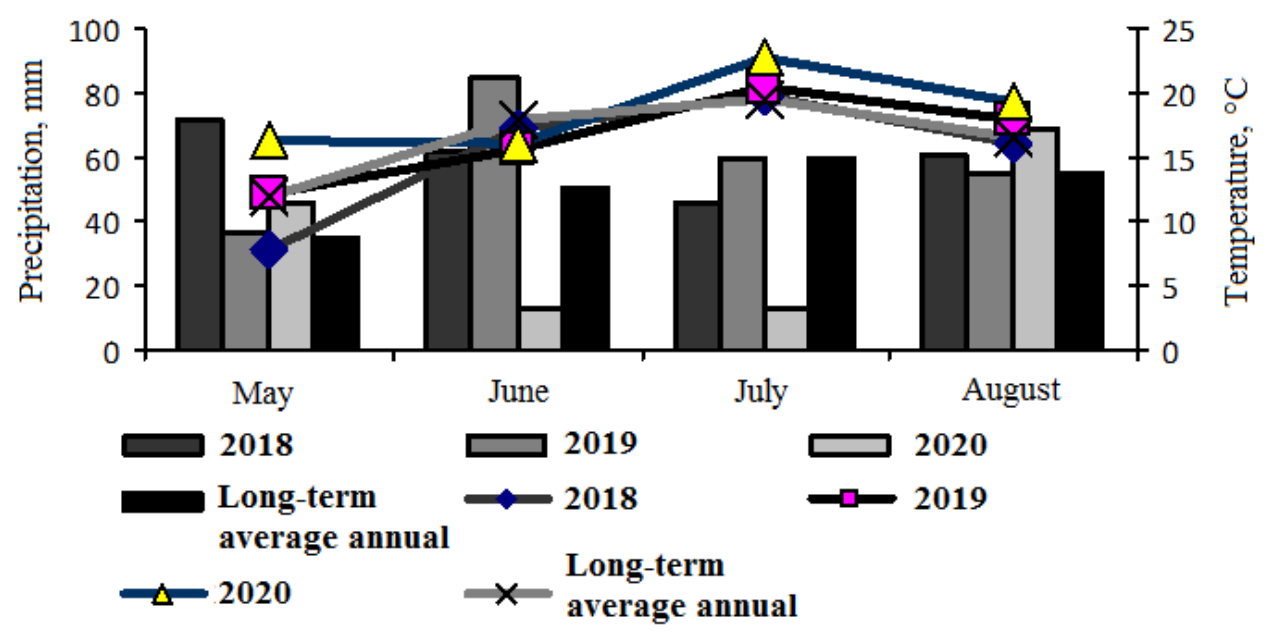

Fig. 2. Precipitation and air temperature of the growing season in 2018-2020.

\section{Research results}

In August 2020, new national interstate standards for oat and barley grain were introduced on the territory of the Russian Federation. Gost 28673-2019 " Oat. Technical conditions" defines uniform standards for assessing the quality of grain of this crop. One of the indicators that indirectly characterizes the cereal properties of oat grain is the grain nature. For food purposes, the grain nature should not be less than $520 \mathrm{~g} / \mathrm{l}$. From the presented Figure 3, it can be seen that, on average, for three years, the most full-fledged grain was distinguished by hulless varieties of oat, which slightly differed in the nature of the grain, with the exception of the Inermis 1194 line.

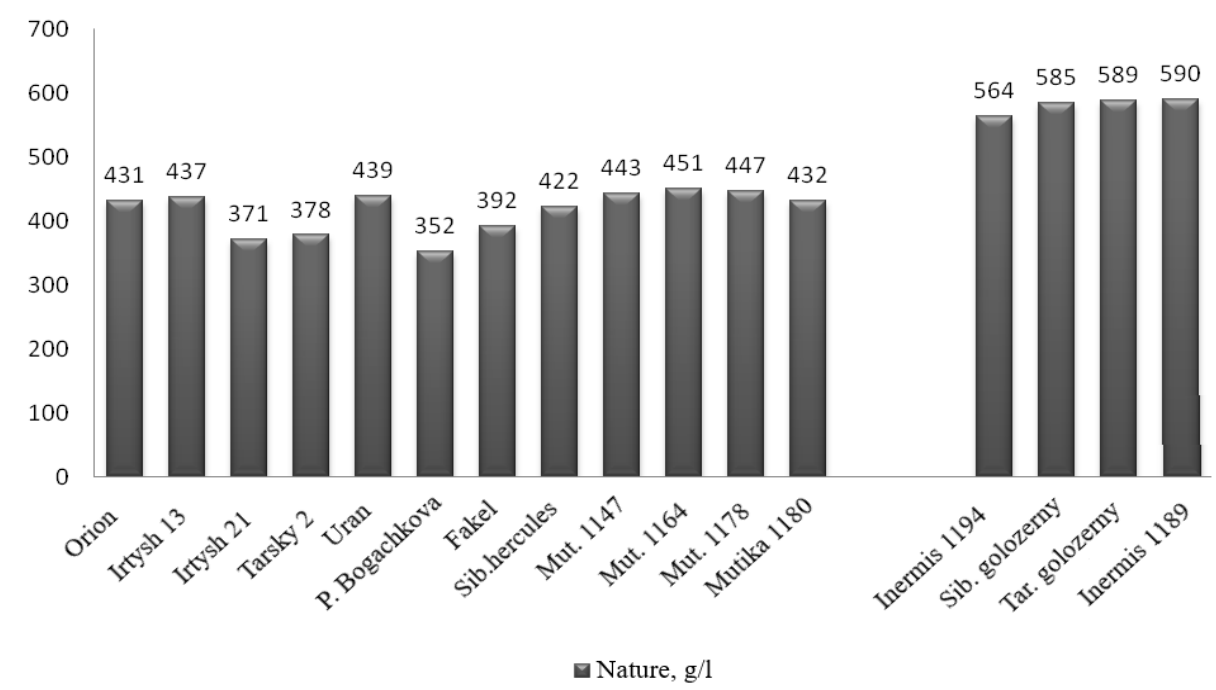

Fig. 3. Grain nature of oat varieties, average for 2018-2020. 
The glumaceous forms did not meet the requirements of GOST Class 3. The maximum value of the trait was obtained in the Mutika breeding line (Mut.) 1164. Comparing the glumaceous and hulless forms, it should be noted that there is a slight variation in the volume weight of grain in hulless varieties $(\mathrm{Vr}=$ from 2.0 to $5.9 \%)$ over the years of the study. The glumaceous forms showed an average resistance to the effects of abiotic factors $(\mathrm{Vr}=5.7 \div 13.3 \%)$. On average, for three years, the nature of glumaceous oat samples varied from 352 to $451 \mathrm{~g} / 1$, in hulless from 564 to $590 \mathrm{~g} / \mathrm{l}$.

Another trait regulated by the standard and characterizing the oat grain suitable for processing is the amount of fine grain, i.e. the passage through a sieve of $1.8 \times 20.0 \mathrm{~mm}$. The presence of fine grain negatively affects the efficiency of processing, because it flakes worse. The proportion of fine grain should be from 3\% (class 1-2) to 5\% (class 3). The samples of glumaceous forms met the requirements of GOST. The share of fine grain in them ranged from 0.06 to $2.66 \%$ (Table 1). For hulless numbers - from 0.91 to $8.56 \%$. In general, hulless forms differ in finer grain. Previous studies have shown that, on average, glumaceous varieties had a longer grain due to glumas $(11.08-11.76 \mathrm{~mm})$, but the grain was made in thickness $(2.47-2.42 \mathrm{~mm})$ and width $(3.01-2.89 \mathrm{~mm})$, and hulless varieties had a short $(8.74-8.79 \mathrm{~mm})$ and narrow grain (thickness - 2.06-2.09 mm and width - 2.43-2.60 $\mathrm{mm})$.

Analyzing the indicator - weight of 1000 grains, which is associated with both grain yield and cereal yield (Table 1), it is worth noting that in glumaceous samples the range of values of the trait was 29.2-43.7 g, and in hulless samples from 27.2 to $33.5 \mathrm{~g}$ (Figure 4).

Table 1. The technological quality of the grain of the selected oat varieties, average for 2018-2020.

\begin{tabular}{|c|c|c|c|c|c|c|c|c|}
\hline Varieties & $\begin{array}{c}\text { Protei } \\
\text { n, } \%\end{array}$ & $\begin{array}{l}\text { Weig } \\
\text { ht of } \\
1000 \\
\text { grains } \\
\text {,g }\end{array}$ & $\begin{array}{c}\text { Natu } \\
\text { re, } \\
\text { g/l }\end{array}$ & $\begin{array}{l}\text { Hull } \\
\text { conte } \\
\text { nt, } \%\end{array}$ & $\begin{array}{c}\text { Alignm } \\
\text { ent, \% }\end{array}$ & $\begin{array}{c}\text { Share } \\
\text { of fine } \\
\text { grain, } \\
\%\end{array}$ & $\begin{array}{c}\text { Yield } \\
\text { of } \\
\text { cereal } \\
\text { s, \% }\end{array}$ & $\begin{array}{c}\text { Yield, } \\
\text { t/ha }\end{array}$ \\
\hline Orion & 12.02 & 37.1 & 431 & 30.6 & 91.7 & 0.21 & 50.9 & 5.07 \\
\hline Irtysh 13 & 11.47 & 32.5 & 437 & 28.3 & 92.6 & 0.96 & 57.5 & 4.84 \\
\hline Irtysh 21 & 10.82 & 30.9 & 371 & 29.9 & 88.8 & 1.81 & 51.0 & 4.56 \\
\hline Tarsky 2 & 10.47 & 34.9 & 378 & 29.4 & 88.6 & 1.18 & 54.4 & 4.96 \\
\hline Uran & 11.19 & 34.9 & 439 & 27.0 & 93.2 & 0.82 & 58.2 & 6.37 \\
\hline $\begin{array}{l}\text { Pamyati } \\
\text { Bogachkova }\end{array}$ & 11.33 & 29.2 & 352 & 32.4 & 80.9 & 1.1 & 47.3 & 4.23 \\
\hline Fakel & 11.13 & 33.4 & 392 & 29.1 & 90.9 & 2.66 & 51.1 & 6.84 \\
\hline Sibirsky Hercules & 11.62 & 34.8 & 422 & 28.9 & 89.1 & 0.06 & 57.7 & 5.44 \\
\hline Mutika 1147 & 13.23 & 39.4 & 443 & 24.3 & 93.3 & 0.15 & 58.0 & 5.50 \\
\hline Mutika 1164 & 12.45 & 43.7 & 451 & 26.6 & 92.4 & 0.19 & 56.0 & 5.77 \\
\hline Mutika 1178 & 14.14 & 35.9 & 447 & 27.0 & 95.5 & 0.26 & 60.8 & 5.97 \\
\hline Mutika 1180 & 12.82 & 31.6 & 432 & 29.1 & 94.8 & 0.79 & 59.3 & 5.99 \\
\hline Average $n=30$ & 12.57 & 33.9 & 414 & 27.0 & 90.7 & 1.24 & 55.8 & 5.47 \\
\hline LSD $_{0.05}$ & 0.69 & 2.5 & 21 & - & - & - & 2.7 & - \\
\hline Sibirsky golozerny & 16.74 & 27.2 & 585 & 0 & 93.5 & 4.15 & 77.1 & 3.99 \\
\hline Tarsky golozerny & 17.00 & 33.5 & 589 & 0 & 97.9 & 0.91 & 71.5 & 4.28 \\
\hline Inermis 1189 & 16.44 & 28.7 & 590 & 0 & 90.6 & 8.56 & 72.5 & 3.89 \\
\hline Inermis 1194 & 16.28 & 29.6 & 564 & 0 & 95.5 & 3.62 & 67.8 & 3.64 \\
\hline Average $n=30$ & 16.98 & 29.5 & 590 & 0.49 & 92.8 & 5.24 & 72.5 & 3.85 \\
\hline $\mathrm{LSD}_{0.05}$ & 0.51 & 4.3 & 19 & - & - & - & 6.1 & - \\
\hline
\end{tabular}

Mutika 1164 (43.7 g) was distinguished from glumaceous samples with a high weight of 1000 grains, from hulless samples - Tarsky golozerny $(33.5 \mathrm{~g})$. At the same time, large grains are crushed more strongly during processing, which leads to an increase in the level 
of flour and a decrease in the yield of cereals, which may be due to the peculiarities of the endosperm structure and the ratio of protein molecules and starch grains. At the same time, the study of varieties according to the grain hardness indicator determined at the agricultural enterprises did not reveal significant differences between the varieties. The weight of 1000 grains varied significantly over the years of the study. To a greater extent, weather conditions influenced the formation of grain size in glumaceous varieties (2018 $\mathrm{Vr}=16.0 \%, 2019-\mathrm{Vr}=10.9 \%, 2020-\mathrm{Vr}=11.7 \%$ ), to a lesser extent in hulless varieties $(2018-\mathrm{Vr}=9.5 \%, 2019-\mathrm{Vr}=13.2 \%, 2020-\mathrm{Vr}=6.8 \%)$.

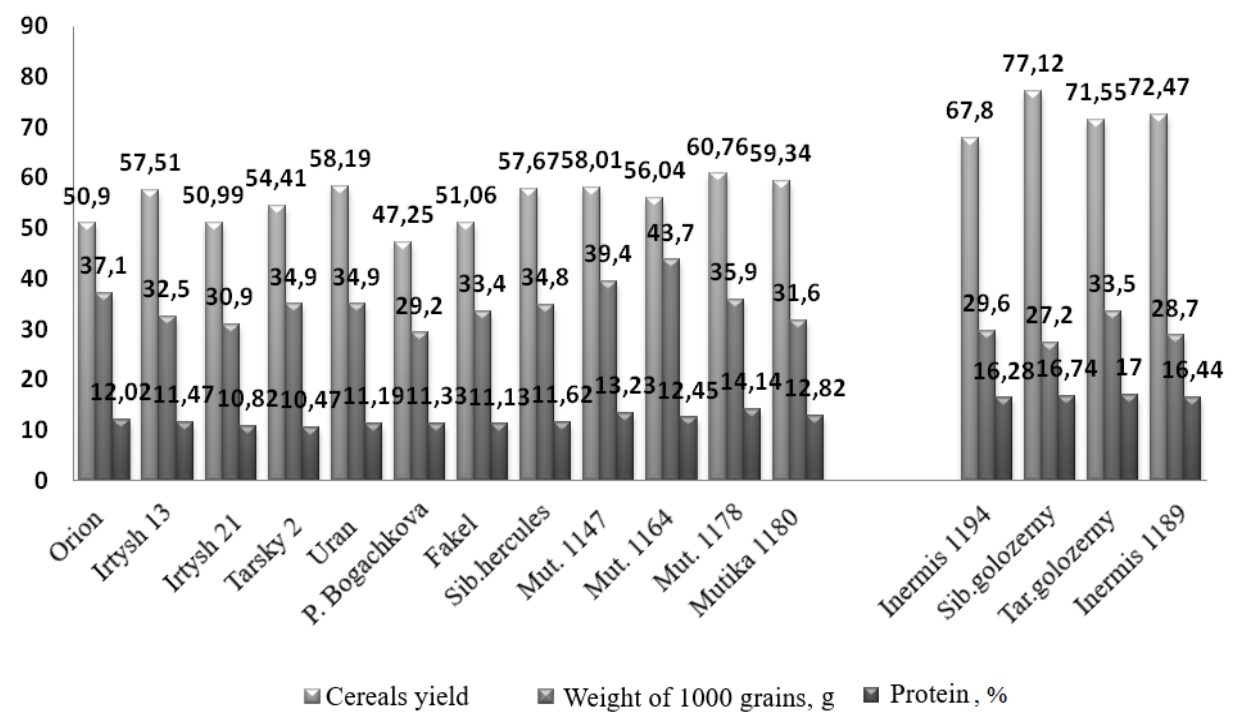

Fig. 4. Cereal Grain yield, weight per grain and protein content in grain in glumaceous and hulless oat varieties, 2018-2020.

To identify the most valuable varieties during their state testing, the assessment is carried out according to the following indicators: hull content (not more than 27\%), equalization (not less than 85\%), cereal yield (not less than 59\%), culinary evaluation of porridge taste is not lower than 4.5 points. Forage varieties are characterized by a higher hull content (29-30\%) and a low yield of cereals (42-44\%).

The selected samples for grain alignment met the requirements of the State Commission from 88.6 to $97.9 \%$ - Table 1 . The hulless samples were more homogeneous $(95.5 \% \div 97.6 \%)$. Another indicator that affects the technological quality of oat grain is hull content. The number of glumas depends on the genetics of the varieties, but more on the weather conditions of the growing season of plants. In the conditions of the southern forest-steppe of Western Siberia, grain with increased hull content is often formed. The variation of this trait was quite high from 24.3 to $32.4 \%$ for glumaceous varieties. A significant proportion of glumas in hulless varieties was noted in $2018-0.2 \div 4.2 \%$. In other years, the selected varieties had practically no glumas. The data is shown in Table 1 . Hulless varieties can have an advantage: the processing technology is simplified, since it is not necessary to release the core from shells.

The nature of the grain, the weight of 1000 grains, the hull content, and alignment indirectly characterize the yield of cereals and its quality. A direct assessment of the technological properties of oat grain is the direct production of cereals and the determination of its yield, culinary qualities. The yield of cereals of oat varieties was determined on the "Satak" Hollander with regulated grain peeling for glumaceous (5 min.) 
and hulless forms (4 min.). The studied indicator in glumaceous samples varied from 47.25 to $60.76 \%$ - Figure 4 . The maximum yield of oatmeal was obtained from the Mutika 1178 variety $(60.8 \%)$. On average, a high level of produced cereals was noted in the varieties Uran and Irtysh 13 (58.2 and 57.5\%, respectively), but below the requirements of the State Commission. In the hulless forms, the yield of oatmeal was quite high in the range of $67.8 \div 77.12 \%$. The maximum yield of the product for an average of three years was shown by the Sibirsky golozerny variety $77.1 \%$. This trait depends on the complex of traits and therefore it is more stable over the years. On average, there was a slight variation in the yield of cereals over the years of research: for glumaceous forms $-\mathrm{Vr}=9.0 \%(2018), \mathrm{Vr}$ $=14.7 \%$ (2019) and $\mathrm{Vr}=6.0 \%$ (2020), and for hulless forms $-\mathrm{Vr}=2.8 \%(2018), \mathrm{Vr}=7.7 \%$ (2019), $\operatorname{Vr}=5.5 \%$ (2020).

The protein content is not regulated by either the standard or the requirements of the State Commission for valuable varieties, but it is an important indicator of the nutritional value of the final product. When breeding oat for cereal properties, preference is given to higher protein forms. A reliable correlation between the protein content in the grain and the yield of cereals $(r=0.91)$ was determined, which allows to select forms with an increased yield of the final product with high nutritional value. The formation of protein in oat grain depends on both the genotype and the weather conditions of the growing season. According to this trait, there was an average variation by year (in glumaceous $-\mathrm{Vr}=11.0 \%$ (2018), $\mathrm{Vr}$ $=11.0 \%$ (2019), $\mathrm{Vr}=8.9 \%$ (2020), and in hulless $-\mathrm{Vr}=7.5 \%$ (2018), $\mathrm{Vr}=9.9 \%$ (2019), $\mathrm{Vr}$ $=5.5 \%$ (2020). On average, for three years, the protein content in grain in glumaceous samples varied from $10.47 \%$ to $14.14 \%$, and in hulless from 16.28 to $17.00 \%$ - Figure 4 . For the entire sample of varieties $(n=30)$, the difference in protein content on average between glumaceous and hulless for three years was from 26.5 to $39.7 \%$, on average $35.1 \%$. The maximum protein level was formed by glumaceous varieties: Mutika 1178 (14.14\%), Mutika 1147 (13.23\%), in hulless varieties - Tarsky golozerny (17.00\%).

On average, for three years, the glumaceous varieties in the competitive variety testing formed a grain yield $29.6 \%$ higher than the hulless ones. The average yield level in glumaceous forms was $5.46 \mathrm{t} / \mathrm{ha}$, in hulless $-3.95 \mathrm{t} / \mathrm{ha}$. The yield of the selected varieties is shown in Table 1. In the glumaceous forms, the Uran variety was distinguished, and in hulless forms - Tarsky golozerny.

The calculation of pair correlations of a sample of varieties for three years revealed ambiguous correlations of the main indicators of grain quality. Table 2 shows the data of the correlation calculation for glumaceous forms.

Table 2. Correlation coefficients between the indicators of the quality of oat grain of glumaceous forms.

\begin{tabular}{|l|l|l|l|l|l|l|l|l|l|l|l|l|l|l|c|}
\hline & \multicolumn{3}{|c|}{ Protein } & \multicolumn{2}{c|}{ Weight of 1000 grains } & \multicolumn{3}{c|}{ Nature } & \multicolumn{3}{c|}{ Hull content } & \multicolumn{3}{c|}{ Fine grain } \\
\cline { 2 - 14 } & 2018 & 2019 & 2020 & 2018 & 2019 & 2020 & 2018 & 2019 & 2020 & 2018 & 2019 & 2020 & 2018 & 2019 & 2020 \\
\hline 1 & $0.47^{*}$ & 0.34 & -0.18 & - & - & - & - & - & - & - & - & - & - & - & - \\
\hline 2 & $0.79^{*}$ & 0.24 & 0.15 & $0.73^{*}$ & $0.52^{*}$ & $0.52^{*}$ & - & - & - & - & - & - & - & - & - \\
\hline 3 & $-0.73^{*}$ & $-0.50^{*}$ & 0.18 & $-0.73^{*}$ & $-0.65^{*}$ & $-0.42^{*}$ & $-0.84^{*}$ & $-0.57^{*}$ & -0.39 & - & - & - & - & - & - \\
\hline 4 & -0.30 & -0.25 & -0.17 & $-0.66^{*}$ & $-0.61^{*}$ & $-0.47^{*}$ & $-0.44^{*}$ & $-0.49^{*}$ & -0.32 & 0.19 & 0.45 & 0.33 & - & - & - \\
\hline 5 & $0.78^{*}$ & 0.03 & 0.15 & $0.61^{*}$ & -0.02 & $0.54^{*}$ & $0.74^{*}$ & 0.23 & $0.72^{*}$ & $-0.77^{*}$ & -0.20 & -0.41 & -0.23 & 0.06 & -0.23 \\
\hline 6 & $0.76^{*}$ & 0.23 & -0.01 & $0.53^{*}$ & $0.50^{*}$ & 0.21 & $0.82^{*}$ & $0.77^{*}$ & $0.53^{*}$ & $-0.74^{*}$ & $-0.68^{*}$ & -0.27 & -0.37 & $-0.50^{*}$ & -0.23 \\
\hline 7 & 0.56 & -0.14 & -0.26 & 0.77 & 0.24 & -0.04 & 0.81 & 0.44 & 0.09 & -0.75 & -0.31 & 0.28 & -0.43 & -0.04 & 0.04 \\
\hline
\end{tabular}

Grain quality indicators: 1 - weight of 1000 grains; 2 - nature; 3 - hull content; 4 - fine grain; 5 alignment; 6 - yield of cereals; 7 - yield; $*$ - significance level $95 \%$ 
The yield of cereals to varying degrees of reliability depended on the formation of such indicators as the weight of 1000 grains, the grain nature, the grain alignment $(r=0.34-0.62)$ with a positive orientation and hull content, the amount of fine grain with a negative orientation. Samples with aligned large grain with a relatively low level of fine grain and reduced hull content were distinguished by a higher nature. Negative correlations were obtained for the indicator weight of 1000 grains with the amount of fine grain and hull content.

For hulless varieties, most of the correlations were weak and unreliable - Table 3. It is possible to note a tendency to increase the yield of cereals in varieties with high indicators of grain nature.

Table 3. Correlation coefficients between the indicators of the quality of oat grain of hulless forms.

\begin{tabular}{|c|c|c|c|c|c|c|c|c|c|c|c|c|c|c|c|}
\hline \multirow{2}{*}{$\begin{array}{l}\text { Indicat } \\
\text { ors }\end{array}$} & \multicolumn{3}{|c|}{ Protein } & \multicolumn{3}{|c|}{ Weight of 1000 grains } & \multicolumn{3}{|c|}{ Nature } & \multicolumn{3}{|c|}{ Fine grain } & \multicolumn{3}{|c|}{ Alignment } \\
\hline & 2018 & 2019 & 2020 & 2018 & 2019 & 2020 & 2018 & 2019 & 2020 & 2018 & 2018 & 2018 & 2018 & 2019 & 2020 \\
\hline $\begin{array}{l}\text { Weight } \\
\text { of } 1000 \\
\text { grains }\end{array}$ & -0.37 & 0.19 & -0.06 & - & - & - & - & - & - & - & - & - & - & - & - \\
\hline Nature & -0.26 & -0.12 & 0.18 & 0.06 & -0.25 & $-0.75^{*}$ & - & - & - & - & - & - & - & - & - \\
\hline $\begin{array}{l}\text { Fine } \\
\text { grain }\end{array}$ & -0.29 & 0.15 & -0.26 & -0.29 & $-0.85^{*}$ & -0.61 & 0.23 & 0.05 & 0.68 & - & - & - & - & - & - \\
\hline $\begin{array}{l}\text { Alignm } \\
\text { ent }\end{array}$ & 0.00 & -0.18 & 0.41 & $0.78^{*}$ & $0.83^{*}$ & -0.59 & -0.18 & -0.05 & 0.33 & -0.66 & $-0.99 *$ & -0.24 & - & - & - \\
\hline $\begin{array}{l}\text { Yield } \\
\text { of } \\
\text { cereals }\end{array}$ & 0.08 & 0.53 & 0.19 & -0.34 & 0.40 & $-0.96^{*}$ & 0.62 & 0.64 & $0.73 *$ & 0.07 & 0.43 & 0.56 & -0.35 & -0.44 & 0.57 \\
\hline
\end{tabular}

* - significance level $95 \%$

The presence of a negative relation between the yield of cereals with an indirect indicator of grain size - a weight of 1000 grains may indicate that an increase in the yield of the finished product in some years can be expected due to the processing of fine grains in hulless forms with lower energy costs.

\section{Conclusions}

1. The advantage of hulless forms in terms of protein content in grain was $35.1 \%$, grain nature by $29.8 \%$, grain yield $-23.0 \%$ higher than that of glumaceous varieties. At the same time, the glumaceous forms formed $76.3 \%$ less fine grain and had a higher yield of $29.6 \%$ and a larger grain of $13 \%$ higher than the hulless forms.

2. Abiotic factors of the growing season of plants have had a greater impact on the formation of such indicators of oat grain quality as the protein content in the grain, the nature and weight of 1000 grains.

3. The breeding of oat varieties for high grain properties is advisable to increase such indicators as the nature of the grain, the weight of 1000 grains and the decrease in the hull content of the grain.

4. For the production of high-quality cereals in the zone of the southern forest-steppe of Western Siberia, it is possible to recommend a high-yielding variety Uran according to the main indicators that meets the requirements for valuable varieties, from bare-grain forms, a larger-grain variety Tarsky golozerny, characterized by high productivity, protein content in grain, nature and a low proportion of fine grain. Of the breeding lines, the glumaceous form Mutika 1178 and the hulless Inermis 1194 and 1189 had preference. The disadvantage of the latter variety is the increased content of fine grain. 


\section{References}

1. I.D. Karotomatov, M.S. Shodieva, Electronic scientific journal "Biology and integrative medicine" 9, 165-185 (2018)

2. A. Chawade, P. Sikora, M. Bräutigam, M. Larsson., V. Vivekanand, M.A. Nakash, Marcus en T.C., O. Olsson, BMC Plant Biology, 86, 60-75 (2010)

3. A.A. Scryabin, I.N. Froltsova, A.A. Antipina, Electronic scientific journal Agricultural Sciences, 5, (2020)

4. M.A. Nikolaeva, L.V. Karatashova, The food industry, 2, 8-13 (2018)

5. L. Moretto, F. Tonolo, A. Folda, V. Scalcon, A. Bindoli, M. Bellamio, E. Feller, M.R. Rigobello, BMC Plant Biology, 3(1), 15-20 (2021)

6. G.A. Batalova, Legumes and cereals 2, 64-69 (2014)

7. G.A. Batalova, S.N. Shevchenko, M.V. Tulyakova and [others], Russian Agricultural Science 5, 7-9 (2016)

8. Yu.V. Kolmakov, S.V. Vasyukevich, E.Yu. Ignatieva and [others], Questions of identifying valuable cereal forms of oat and barley: methodological recommendations, 56 (Omsk: LLC RPC "Sphere", 2012)

9. Methodology of the state variety testing of agricultural crops, 121 (Moscow, 2012)

10. B.A. Dospekhov, Methods of field experience, 335 (M., "Kolos", 1968) 